\title{
Circular Migration and Triple Benefits: The Case of Albanian Migrants to Italy
}

\author{
Mejola Kodra \\ Institute of European Studies, \\ University of Tirana, Elbasan St, \\ Tirana, Albania
}

DOI: https://doi.org/10.36941/mjss-2021-0025

\begin{abstract}
According to the 2008 IOM Report on Migration in the World, circular migration is "the fluid movement of people between countries, including temporary or long-term movements, which can be beneficial to all entities involved, if it happens voluntarily and if it is related to the labor market needs of the countries of origin and destination." The already 30-year experience of emigration of Albanians to Italy has shaped new models of migration. The historical migration between the two countries, as well as the long migratory experience after the fall of the communist regime, has enabled the circulation of many individuals between the two countries.The purpose of this study is to explore through the experiences of migrants moving between Albania and Italy, their contribution to themselves, as well as for the host country and that of origin. This paper is based on a combination of data obtained from secondary sources, such as: studies and research by foreign and Albanian authors, reports and literature focused mainly on circular migrants, but not only, as well as primary data obtained from direct interviews and focus groups with 15 circular migrants. Based on the perceptions generated by the migrants themselves, who participated in this study, there seems to be a threefold benefit from this migration process, despite the fact that migrants' perceptions take on different nuances in relation to these benefits that sometimes lean more towards themselves, sometimes from the host country and sometimes from the country of origin. Throughout the interviews it was noted that migrants did not know policies in support of this category, either from the host country or from the country of origin, which can be considered as an important step to be taken in the framework of interstate cooperation, to increase the triple benefit from this type of migration.
\end{abstract}

Keywords: circular migration, triple fold benefit, Albania, Italy

\section{Introduction}

According to the 2008 IOM Report on Migration in the World, circular migration is "the flow (the fluid movement) of people between countries, including temporary or long-term movements, which can be beneficial to all entities involved, if it occurs voluntarily and if it relates to the labor market needs of the countries of origin and destination" (IOM, 2008).

Thus, what is noticed in this definition is that it is a movement of individuals, whether longterm or short-term, not a movement within the country, but a movement of international character.

The purpose of this study is to explore through the experiences of migrants circulating between 
Albania and Italy, their contribution to themselves, as well as to the host and country of origin.

In order to achieve this goal, 3 objectives have been set: (a) To examine the causes that generate circular migration between Albania and Italy (b) To identify the types of circular migration between Albania and Italy (c) to analyze the benefits from circular migrants for themselves, for the host country and the country of origin, known as the "triple fold benefit".

The emigration of Albanians to Italy is a very important process of the post-communist period of Albania, which has played and still continues to play an important role in the socio-economic and political developments of Albania, but also of the host country, Italy.

The first part of this paper focuses on explaining the concept of migration, the European experience, the reasons for the circulation and the explanation of the threefold benefit of this type of migration.

In the second part, a description of the migration between Albania and Italy, the causes and typologies of this migration is given.

In the third part, the findings of an empirical study based on the qualitative interview method are presented. This chapter speaks, as it were, in the language of the circulating migrants themselves and explores their direct experiences, to highlight their threefold contribution: for themselves, for the host country as well as for the country of origin.

The last part of this article provides some conclusions and suggestions on how to maximize the triple benefit of circulating migrants.

\section{Methodology}

This article is based on a combination of data obtained from secondary sources, such as: studies and research by foreign and Albanian authors, reports and literature focused mainly on circulating migrants, but not only, as well as primary data obtained from live interviews and focus groups with 15 circular migrants. The snowball technique was used to recruit the interviewees and the intentional sample was used to include the interviewees in the study. The data were processed through thematic analysis, which was guided by the data collected from a semi-structured interview guide.

\section{Literature Review: Circulating Migrants, Reasons for Migration and Triple Benefits}

According to the litterature, the movement (flow) with a circulating character is related, on one hand, to the benefits of the circulating entities themselves, but on the other hand to the employment demands generated by the host countries. In other words, in the contemporary literature, circular migration is considered a "triple profit" process (Ibid.) for three beneficial parties: (a) persons who emigrate, because they decide to migrate when they consider that there are more opportunities for them to be employed in the host country; (b) host countries, because they fill vacancies in employment, even seasonally, with circular migrants, but also (c) countries of origin, which benefit from remittances that migrants bring, without losing these citizens, who return continuously and/or periodically to the country of origin (EMN, 2010: 5).

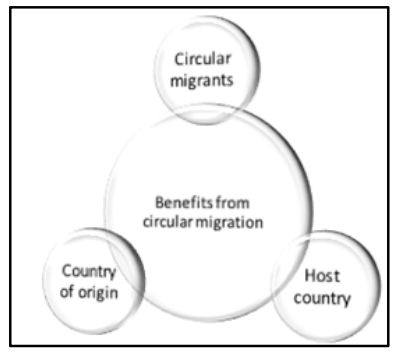

Figure no. 1. Triple benefits from circular migration 
Statistical identification of circular migrants is difficult because they may be citizens of both countries, or may be provided with a residence permit in both countries and it is difficult to obtain official data on them. Of course, controlling the border movements of these people would be practically too sophisticated and complex to use for research purposes, so statistics can only record cases of circular migration for seasonal employment purposes.

Circular migrants, otherwise known as "repeating" migrants, may have different reasons for moving from their country of origin to a host country. Some of them are temporarily employed in the host country and upon termination of the contract they return to their country of origin to reimmigrate again, once they have secured a new employment contract. Some others migrate periodically for health reasons, especially the chronically ill, because in the host country they receive better health care compared to that of their country of origin. Others move between the host country and the country of origin for business reasons, because they have established partnerships in the host country and manage the business with the country of origin. While others split the year between the country of origin and the host country for climatic and tourist reasons, i.e. stay in the host country along the most favorable seasons and usually when the season is suitable in the country of origin, they return home.

Some others, who are qualified professionals, due to the nature of their work, come and go through the company branches in different countries of the world or acquire periodic contracts with similar companies, thus creating a short-term migration circulation model, regulated by employment procedures.

Various studies have highlighted some demographic characteristics of circulating migrants. Thus, for example, in a study conducted in 2010, Constant and Zimmermann identified that immigrants from European Community countries at a young age and those in old age were more likely to repeat the experience in migration and stay longer in host country, compared to middleaged migrants. Men and those who held a host country passport migrate more often than women and those who did not hold such a document. People with higher education migrate (repeatedly) less often compared to those with lower level of education. Migrants whose families are in the country of origin are more likely to stay longer in this country compared to others (Constant and Zimmermann, 2011).

Researcher Zimmerman presents the advantages and difficulties of this type of emigration. In a summary table, they are presented as follows:

Table no. 1. Advantages and difficulties of circular migration

\begin{tabular}{|l|l|}
\hline \multicolumn{1}{|c|}{ Advantages } & \multicolumn{1}{c|}{ Difficulties } \\
\hline Circular migrants fill vacancies in host countries. & $\begin{array}{l}\text { Restrictive measures related to circular migration increase } \\
\text { the possibility of illegal migration and visa violations in } \\
\text { host countries. }\end{array}$ \\
\hline $\begin{array}{l}\text { Circular migrants do not stay in the host country if } \\
\text { they do not find work, so illegal migration to these } \\
\text { countries is avoided. }\end{array}$ & $\begin{array}{l}\text { Austerity measures can affect non-economic migrants, } \\
\text { their families and people benefiting from social assistance } \\
\text { schemes. }\end{array}$ \\
\hline $\begin{array}{l}\text { Remittances sent to the country of origin affect the } \\
\text { economic development of these countries. }\end{array}$ & $\begin{array}{l}\text { Circular migration can create labor shortage problems in } \\
\text { countries of origin. }\end{array}$ \\
\hline $\begin{array}{l}\text { Circular migrants reduce brain drain and encourage } \\
\text { the transfer of knowledge and skills, known as "brain } \\
\text { circulation". }\end{array}$ & $\begin{array}{l}\text { Circular migrants may be "stuck" in unskilled work and } \\
\text { may be exposed to abuse, exclusion and discrimination. }\end{array}$ \\
\hline
\end{tabular}

\section{Source: Zimmermann, 2010}

Internationally, the concept of circular migration has its roots in practices already widely known in Europe, such as post-war reconstruction, for example, with the Gastarbeiter Programs established since then in West Germany with "guest workers" from Southern and Eastern Europe as well as 
Turkey. In the years 1950-1960, millions of unskilled workers from southern Europe left their jobs to work in the industrial sector in North Germany and other Western European countries, where labor shortages had slowed the economic growth of these countries (Zimmermann, 2002).

Migration seems to never be a final process. The migratory project may be temporary, but may become permanent, or an unsustainable project, as is the case of migrants moving between the country of origin and the host country or other host countries. In this case, circulating migrants promote international social networks, transmitting information from host countries to the country of origin, especially for potential migrants, but also linking jobseekers in the country of origin with employers in the host country. They not only fill vacancies in the host country, but also maintain low wage levels in these countries, help reduce population aging, and reduce illegal immigration (Vertovec, 2008). Circulating migrants also play a very important role for the country of origin. Circulating immigrants tend to send more money home, compared to other immigrants, who intending to stay permanently in the host country they send less money to the country of origin (Constant and Zimmermann, 2011).

\section{Circular Migration Between Albania and Italy, Reasons and Typologies}

The latest data recorded on January 1, 2020, show a figure of 421,591 Albanian immigrants residing in Italy, out of a total of 5,039,637 foreign immigrants in Italy ${ }^{1}$. Considering the number of naturalized Albanians in Italy, ie those who enjoy Italian citizenship and are provided Italian passports, the presence of Albanian emigrants in Italy should be much higher.

After 30 years of emigration, there is some evidence that Albanian emigrants in Italy are best integrated in Italy. According to researcher Nick Mai (2011: 7), this is evidenced by:

a) Dispersal of Albanians in all regions of Italy, ie Albanians are not inclined to be grouped together or to create ghettos;

b) The demographic composition of Albanian emigrants in Italy, which is heterogeneous, for example the presence of girls and women has been increasing, thus leading to what Bonifazi and Sabatino consider a demographic "normalization" (Bonifazi and Sabatino, 2003: 970). Thus on January 1, 2020, there were 206,106 girls and women in Italy, compared to 215,285 boys and men; ${ }^{2}$

c) The high number of enrollments of Albanian emigrant children in Italian schools. Thus in the academic year 2004-2005, 1 in 4 foreign students that enrolled in universities, was Albanian. Even in 2016, Italy continued to be the most preferred country by Albanian students. According to Eurostat data in Italy in 2016, about 10,724 Albanian students were enrolled in Italian universities ${ }^{3}$. While in 2018 in Italian universities there were enrolled 10,364 students, which constitute about 60 percent of all students enrolled that year in universities outside Albania. ${ }^{4}$

d) Mixed marriages between Italians and Albanians are also an important indicator of integration. The data show that, although Albanians are one of the groups that have married locals, the level of marriages remains low compared to marriages that individuals of other nationalities perform with locals. This tendency, rather than an indication of ongoing stigma, may also be indicative of an endogamy among Albanians due to their strong family and tribal traditions and a balanced gender level (Mai, 2011: 7).

As the researcher Nick Mai claims, beyond these indicators that testify to a satisfactory level of integration, Albanian emigrants have faced and felt prejudices from locals, which in a large part have

\footnotetext{
${ }^{1}$ Look: Albanesi in Italia, https://www.tuttitalia.it/statistiche/cittadini-stranieri/34lbanes/, accessed 21.04.2021

${ }^{2}$ Look: https://www.tuttitalia.it/statistiche/cittadini-stranieri/albania/, accessed 10.12.2020.

${ }^{3}$ Look: http://www.balkanweb.com/wp-content/uploads/2018/11/studentet-shqiptare.png, accessed 12.04.2021.

${ }^{4}$ Look: International Trade Administration Albania - Education and Training | Privacy Shield, https://www.privacyshield.gov/article?id=Albania-Education-and-Training, accessed 12.04.2021.
} 
been encouraged by the media. Thus, the refusal to let them a house or hire them has not been insignificant throughout the migration experience of Albanians in Italy. The internalization of these prejudices is also a process, which has affected Albanian emigrants in Italy. Thus, under the influence of these prejudices, many Albanian emigrants, at least at the beginning of their migration experience, preferred to be "disguised" as natives (Ibid.). Researcher Vincenzo Romania has called this phenomenon "social mimeticism" which manifests itself as a reaction to negative stereotypes built around the image of the alien (Romania, 2004). Another way to react negatively to stigma is to use the Italian language among Albanian immigrants and even encourage children to use the Italian language not only in school but also in public (Mai, 2011: 7).

The stigmatization the natives put towards the emigrants seems to be reawakened at certain moments, despite the "periods of calm". Thus, the experience of the economic crisis, which began in 2008, showed that the stigma towards foreigners tends to be highlighted when employment opportunities are reduced for locals. Under these conditions, immigrants become undesirable because "they take jobs from locals."

This feeling of being a foreigner can occasionally generate, among immigrants, the desire to return to their country of origin, so fitting to the term circulating immigrants.

In a study published in the framework of the METEIKOS project, cited above, entitled "Reluctant turnovers, the interaction between integration, return and circular migration within the Albanian migration to Italy", 5 types of circular migration of Albanians to Italy have been identified:

1. Seasonal workers (agriculture, tourism, farming), of legal and technical type. The latter are accompanied by residence and work permits that do not correspond to the seasonal character of the work they do.

2. Students returning to Albania to work in universities, public administration, the third sector (services) and, to a lesser extent, the private sector, maintaining links with Italy. This category also includes students who study and live in Italy and who regularly visit Albania.

3. Entrepreneurial migrants residing in Italy and setting up a parallel business firm in Albania in order to start building a future between Italy and Albania and employ their relatives, especially in the construction industry. This category includes returnees or successful entrepreneurs, based in Albania and who need to be in Italy very often as part of their managerial work in import, export, etc.

4. Documented returnees: i.e migrants with Italian citizenship or with a permanent / longterm permit ( $5+$ years) to stay in Italy, who returned to Albania after feeling that their migratory experience had been fulfilled, but who still have a structural link with Italy for employment, family, health services and study.

5. Economic returnees: ie. migrants who, having returned to Albania as a result of the economic crisis in Italy and due to the temporary and informal nature of their employment in Italy, are planning to return to Italy to work in the future and keep Italian documents and / or to obtain citizenship or renew a residence permit. This category includes migrants who were "deported" and / or decided to return to Italy repeatedly and irregularly to earn a living for themselves and their families (Mai, 2011: 9-10).

Keeping in mind these typologies, throughout this study, by the use of deliberate sampling, an attempt has been made to explore the experiences of circular migrants from all 5 of the above categories.

\section{Findings and Disscusion}

Through semi-structured interviews with circular migrants, several factors were identified that have driven this migration between Albania and Italy. They are listed below. 
5.1 The global economic crisis, which strongly affected Italy in 2008 and which removed many Albanian emigrants from the labor market.

The economic crisis which started in 2008, affected in different ways immigrants with variable socioeconomic status. Thus, for example, those who were documented and employed in Italy were not inclined to return, while others who remained unemployed and were not provided with a residence permit in Italy were inclined to return to the country of origin.

Here is what P.M, 51, says.

"My documents were not renewed because I could not find a contract job. I said, "I will go back to my home country" For better or worse, I said I would find a job in Albania. Afterall I had my home there, I had my family there. Nothing can keep me longer in Italy. When I returned it was not easy to adapt to Albania as well. Those months when I was out of work seemed like years to me. Now I work for a company that deals with the installation of air conditioners, like the job I had in Italy. A cousin of mine from Italy found me this job in Albania, because of connections that he had with someone who knew my Italian boss. Now I come and go from Italy whenever it is necessary for the firm. We have established a very good relationship of trust with this business owner ."

It seems that connecting and maintaining relationships with acquaintances in the host country, constitutes a very important element that favors circular migration and feeds it from time to time.

5.2 Creation of trade cooperation links between Albanian partners living in Albania and Italy, but also between them and the Italian ones.

The partnership between Albanians and Italians seems to have arisen as a common need to positively use the opportunity to develop enterprises, both by Albanian and Italian entrepreneurs.

Here is what M.K, 49, who has lived in the province of Tuscany for 21 years, states:

"When I came back in 2009, I completely lost hope that I would ever return to Italy. The situation there seemed hopeless. However, when I came to Albania, I remained in touch with friends in Italy and one of them gave me the idea to open a business. It was not easy at that time when Albania was almost full with such kind of businesses, but nervertheless we dared. We had nothing to lose. Italy plunged into crisis and there was no more work for us. We have a company that deals with aluminium structures now and we get the raw material from Italy, where this friend of mine has become a courier.The work is not all flowers but we can still manage alright."

5.3 Increased stigma and prejudice as well as discriminatory attitudes of locals towards immigrants in general and Albanian emigrants in particular, after the 2008 crisis.

As mentioned above, crisis situations generally increase the level of xenophobia. The Observatory on Xenophobia and Racism, conducted by the Italian Chamber of Deputies in 2010, showed that 49 percent of respondents think that Italians should be given priority in employment (Riccuci, 2011: 47).

K.M, 55, claims:

"I could not stay in Italy anymore, sister. We felt ourselves as foreigners for long 17 years. Great stress whenever the period came to renew the documents. And the locals started to know us so we did not feel any racism (discrimination, - M.K.) from those who knew us, but rather from the official treatment. Then those who did not know us when they heard our name and surname, being foreigners as such, did not show any desire to approach us. In your own country, for good or for bad, you feel at home."

5.4 Visa liberalization of Albania in 2010 enabled a kind of circulation for the purpose of informal employment of Albanians.

V.SH, 47 years old, mother of three children and resident in Durrës, during her interview states that 
she did not have any documents to enable her stay in Italy, but had used the liberalization of the visa regime to circulate between Albania and Italy .

\begin{abstract}
"After 2010, when visas were liberalized, we had the right to go to Italy for 3 months and come and stay in Albania for 3 months. To be honest, despite the fact that I was not allowed to work for those 3 months, I saw it as a good solution to make some money, in black market. What we did was, through my sister who lives in Italy, we found an elderly man who needed service, and for 3 months I went to take care of him and for another three months my other sister, who also lives in Albania. Whatever we did, we had children to raise and educate them."
\end{abstract}

\title{
5.5 The situation created by COVID 19, encouraged circular migration
}

The situation created by COVID 19, during which Italy emerged as one of the most affected countries, with a high number of victims and the application of some of the most austerity measures in the world prompted many Albanian emigrants to return to Albania, working or studying online or even going to Italy (in person) periodically for short periods.

F.K, 25 years old, who has been living in Italy for 2 years, states:

"I am a student at Bocconi University in Italy. I always came to Albania for a month in December and 2 months in the summer because I miss a lot of people at home, but this year I stayed much longer, almost all year. The teaching was online and this favored my stay in Albania. It is discussed that online teaching will take place in university studies and will be combined in classroom teaching even after the end of the pandemic. We do not know what will happen, but if so, I will stay for longer periods in Albania "

I.R., a 37-year-old Italian graduate with a degree in programming engineering, states:

"I work as an IT engineer in an Italian company in Bolzano. It is in fact a company that is, so to speak, a subsidiary of a German company. I have often travelled to and fro Italy-Germany for work reasons, but because of Covid-19, I have been living in Albania for many years now and I work from my parents' house. I don't even pay rent here and I get my food ready [Laughs]. Now I have created a business plan to remotely manage a company of my own."

SH.R., 61 years old, who has been living in Italy for about 30 years, states:

"Italy was completely closed and continues to be closed. You get a bad feeling from isolation. Now that we have Italian passports and no other obligations, we decided to return to Albania. Here,Covid virus is not felt so much and psychologically we feel calmer. It has been two years almost. We also bought a house on the beach and from May to October we will stay here and spend the winter in Italy. The Virus "taugh" us this and it turns out we have started to like it [Laughs]."

5.6 The retirement of many Albanian emigrants in Italy enables them to be free to move between Albania and Italy.

Ë. SH. 69 years old, originally from Pogradec, but living in Durrës, tells the experience of herself and her husband as circular emigrants in Italy.

"We have a 10-year permesso di soggiorno (residence permit, - M.K.). Our daughter, who lives in Ancona, helped us with the documents. To be honest, when in Italy we really do not belong there, but we go from time to time to help our daughter because she has small children to raise. We also get our medicines and have medical visits, because to be honest, Italy is very good at medicinal field. We were stuck in Italy for 4 months and we had already started to miss home a lot. People of our age do not belong in Italy, but life situations lead us to." 


\title{
5.7 Freelance professionals in circulation
}

In contemporary literature, the terms "Brain drain", "Brain gain" and "brain circulation" are very popular. During the period 1990-2008, 40.6 percent of university lecturers and research staff migrated from Albania, and not all of them worked in their profession in the targeted countries where they emigrated (Gëdeshi, 2008), becoming part of the process known as "brain waste" (brain loss). Even so, experience also recognizes quite a few cases of professionals continuing to circulate between origin and host countries.

The departure of professionals is a phenomenon that started in the 1990s from Albania to Western countries, but still continues to be relevant today.

Here is what M.L, 41, an architect, says:

"It has been about 11 years now that I have been here and there. Working as an architect has favored me to enter into good contracts both in Italy and Belgium. I believe that now I would not be able to live in one place. My family lives in Albania, but they are also used with my lifestyle now. Online communication keeps us very connected when I'm not there"

Regarding the triple impact of turnover emigration, the participants in the interview process are divided into 3 categories:

a) Those who think that this influence is really triple fold, themselves, the host country and the country of origin; all parties benefit from their circulation.

b) Those who minimize the benefit of the country of origin

c) Those who minimize the benefit of the host country

d) Those who minimize the benefit of both the country of origin and the host country and emphasize personal benefits.

Most of the respondents associate the benefit directly with themselves.

Here is how K.L, 61 years old, agronomist by profession, says.

"I do not know what my life would have been like, if that "Italian door" had not been opened for me. Italy, and especially Tuscany, where I lived, made me perfect in my craft as an agronomist. Now I have my farm here in Albania and things are going well for me in general. I often go to Italy to maintain cooperation with my colleagues and friends there, who I can rely to for any of my needs."

Regarding the host country, the emigrants claim that Italy has generally benefited a lot from their work. Emigrants emphasize that especially at the beginning of the migratory experience, Albanian emigrants did jobs that the Italians themselves no longer preferred.

M.Z, 64 years old states:

\begin{abstract}
"Especially in the beginning we "cleaned" Italy with our nails, we kept those Italian old men and women, we did every job that the Italians themselves did not do. The sacrifices were too big for us. I am not saying that the Italians have not appreciated us, except in rare cases. They have acknowledged and accepted us in their homes and made us friends, but we have also worked hard. There are way too many Albanians that pay contributions for italian elders to receive their pensions in Italy. I think we have given them more than they have given to us."
\end{abstract}

Analyzing the perceptions of circular migrants, it is noted that the benefit of the country of origin is emphasized, especially in relation to new knowledge (know-how) that is imported from western countries where migrants have circulated to countries of origin. There are those who think that despite this new imported knowledge, Albania has not made significant structural changes.

Here is the comment of I. B, an urban planner graduated in Italy, who together with her husband have opened a joint studio and work in Albania: 
"I think that emigration to Italy serves as a cultural bridge with Europe and the perception of what is European. The steps that Albania has taken seem to me sufficient in the cultural aspect, but nonexistent in the structural aspect of the state functioning at almost every level. The emigrants who return consequently set an example in Albania."

\section{Conclusions}

The 30-year experience of emigration of Albanians to Italy has shaped new models of emigration. Influenced by globalization processes, as well as the intensification of communication through virtual platforms, circular migration is intensifying even more. Many factors related to the geographical and historical proximity between the two countries, as well as the long migratory experience after the fall of the communist regime, has enabled the circulation of a large number of individuals. Based on the perceptions generated by the circulating migrants themselves, who participated in this study, there seems to be a threefold benefit from this migration process, despite the fact that migrants' perceptions take on different nuances in relation to these benefits that sometimes lean more towards themselves, sometimes towards the host country and other times towards the country of origin. Throughout the interviews it was noted that circulating migrants had little or no knowledge at all of the policies in support of this category, either from the host country or from the country of origin, which can be considered as an important step to be taken in the framework of interstate cooperation, to maximize the triple benefit from this type of emigration.

\section{References}

Albanesi in Italia, https://www.tuttitalia.it/statistiche/cittadini-stranieri/39lbanes/, accessed 21.04.2021

Bonifazi, C. and Sabatino, D. (2003) 'Albanian migration to Italy: what official data and survey results can reveal', Journal of Ethnic and Migration Studies 29(6): 967-995., pg.97o.

Constant, A.F., Zimmermann, K.F. (2011) Circular and Repeat Migration: Counts of Exits and Years Away from the Host Country. Popul Res Policy Rev 3o, 495-515. https://doi.org/10.1007/s11113-010-9198-6, accessed 12.04.2021.

European Migration Network, Migrazione temporanea e circolare in italia: evidenze empiriche, prassi politiche attuali e opzioni per il future, Roma 2010. pg. 5. https://ec.europa.eu/home-affairs/sites/default/files/whatwe-do/networks/european_migration_network/reports/docs/emn-studies/circular-

migration/14b._italy_national_report_circular_migration_version_13oct2010_it.pdf, accessed 16.03.2021.

Gëdeshi, I., (2008) The relationship between migration and socio-economic changes in Albania, Der Donauraum, 48(3): 197-292; World Bank (2010) Albania, the New Growth Agenda: A Country Economic Memorandum. Washington DC: World Bank Report No. 53599-AL, accessed 16.12.2020

http://www.balkanweb.com/wp-content/uploads/2018/11/studentet-shqiptare.png.accessed 12.04.2021.

https://www.tuttitalia.it/statistiche/cittadini-stranieri/albania/, accessed 10.12.2020

International Trade Administration Albania - Education and Training | Privacy Shield, https://www.privacyshield.gov/article?id=Albania-Education-and-Training, accessed 12.04.2021.

IOM, (2008). World Migration Report 2008, Geneva.

Mai, N., Reluctant circularities: the interplay between integration, return and circular migration within the Albanian migration to Italy. European University Institute (Meteicos project), 2011.

Riccuci, R., (2011). Le famiglie straniere di fronte alla crisi istantanee piemontesi, Rapporto di ricerca Fieri.

Romania, V., (2004). Fare Passare per Italiani: Strategie di Mimetismo Sociale, Carocci, Roma.

Vertovec, S. (2008). Circular migration: The way forward in global policy Canadian Diversity 6:3: 36-40.

Zimmermann, K. F. (2002). European migration: Push and pull" In: Zimmermann, K. F., Bauer, T. (eds). The Economics of Migration. Cheltenham, UK: Edward Elgar.

Zimmermann, K.F. (2010). Circular migration. Why restricting labor mobility can be counterproductive, IZA, World of Labor. https://wol.iza.org/uploads/articles/1/pdfs/circular-migration.pdf?v=1, accessed 12.03.2021. 